\title{
APLIKASI TEKNOLOGI BIO-BALITANI DALAM PRODUKSI BIOURINE DI KELOMPOK TANI ARSA WINANGUN DI DESA TARO
}

\section{Bio-Balitani Technology Aplicaton for Biourine Production in Tani Arsa Winangun Group of Taro Village}

\section{Ardina Ratna Pramesti, I Made Arba Rahastra, Ni Putu Dewi Tata Arini, Komang Rita Noviyanti, Putu Erika Nandia, I Made Mudita}

Program Studi Peternakan Universitas Udayana BALI

Jalan Kampus Bukit Jimbaran, Denpasar, Bali, Indonesia 80361

Alamat korespondensi: ardinapramesti1@gmail.com

(Tanggal Submission: 29 July 2021, Tanggal Accepted : 6 Desember 2021)

\begin{abstract}
Kata Kunci : Abstrak :
Bio-Balitani, Teknologi pemanfaatan urin ternak menjadi pupuk organik cair penting diketahui Biourine, untuk mengurangi resiko pencemaran lingkungan yang disebabkan oleh limbah Fermentasi, kotoran ternak yang tidak diolah dengan baik. Desiminasi teknologi fermentasi Inokulan melalui pemanfaatan produk Bio-BaliTani yang diproduksi memanfaatkan konsorsium bakteri Lignosellulolitik asal rumen sapi bali dan rayap merupakan salah satu inovasi yang dikembangkan untuk menanggulangi berbagai permasalahan yang ada di Kelompok Tani Arsa Winangun. Kegiatan pengabdian kepada masyarakat ini bertujuan untuk mengatasi kurangnya pengetahuan dan keterampilan Kelompok Tani Arsa Winangun dalam pengelolaan limbah peternakan yang dihasilkan. Hasil pelaksanaan kegiatan menunjukkan bahwa Kelompok Tani Arsa Winangun mampu menyerap dan mengaplikasikan teknologi yang di diseminasikan. Hal ini ditunjukkan dengan adanya kemampuan dari kelompok tersebut dalam memproduksi biourine dengan memanfaatkan teknologi Bio-BaliTani. Hasil analisis kandungan hara biourine yang diproduksi juga menunjukkan bahwa biourine memiliki kualitas baik dan mampu memenuhi standar SNI No.19-7030-2004.
\end{abstract}

Panduan sitasi / Citation guidance (APPA $7^{\text {th }}$ edition) :

Pramesti, A.r., Rahastra, I.M.A., Arini, N.P.D.T., Noviyanti, K.R., Nandia, P.E., Mudita, I.M. (2021). Aplikasi Teknologi Bio-Balitani Dalam Produksi Biourine di Kelompok Tani Arsa Winangun Di Desa Taro. Abdi Insani, 8 (3), 283-286. http://doi.org/10.29303/abdiinsani.v8i3.408

\section{PENDAHULUAN}

Desa Taro adalah sebuah desa yang terletak di dataran tinggi di Kecamatan Tegallalang, Kabupaten Gianyar, yang membuat suhu di Desa Taro sangat sejuk dikala siang maupun malam hari. Hal ini juga didukung dengan masih banyaknya pepohonan yang terjaga kelestariannya serta masih 
banyak lahan $( \pm 68 \%)$ yang digunakan sebagai lahan pertanian yang mempertegas corak agraris bagi Desa Taro.

Di Desa Taro pemeliharaan ternak sapi bali (normal) dilaksanakan secara mandiri oleh setiap pemilik ternak, yang saat ini telah menghimpun diri dalam wadah kelompok tani yang bernama Kelompok Tani Arsa Winangun. Kelompok ini merupakan kelompok tani-ternak yang sedang dalam pengembangan usaha peternakan sapi Bali di Desa Taro. Berlokasi di Banjar Dinas Taro Kaja, beranggotakan 22 orang dan saat ini mempunyai 22 ekor sapi bali. Kelompok tani Arsa Winangun telah mengembangkan usaha peternakan sapinya dalam 1 areal usaha milik kelompok dengan luas 5 are, serta didukung areal penanaman hijauan makanan ternak seluas 60 are, sehingga komunikasi dan koordinasi dalam pengembangan usaha peternakan dapat dilaksanakan dengan lebih efektif. Usaha yang dikembangkan oleh kelompok tani tersebut sampai saat ini baru sebatas usaha produksi ternak seperti pembibitan dan penggemukan sapi bali, sedangkan usaha pengolahan feses dan urine menjadi pupuk organik belum dijalankan dengan baik. Hanya pada waktu tertentu kotoran ternak dimanfaatkan sebagai pupuk, itupun untuk keperluan sendiri.

Berdasarkan kondisi tersebut, peningkatan pengetahuan petani/peternak maupun dalam optimalisasi usaha beternak sangat penting dilakukan. Teknologi yang didiseminasikan merupakan teknologi yang mudah digunakan oleh masyarakat termasuk oleh petani sampai peternak (Mudita et al., 2009). Penyediaan pakan berkualitas serta pengolahan limbah usaha peternakan menjadi produk bernilai ekonomi sangat penting dilakukan untuk meningkatkan ekonomi peternakan melalui peningkatan pendapatan dan sumber penghasilan tambahan bagi petani dan kelompok tani secara keseluruhan.

Teknologi Bio-BaliTani merupakan teknologi yang berbasiskan teknologi fermentasi memanfaatkan isolat bakteri probiotik lignoselulolitik unggul asal cairan rumen sapi bali dan rayap yaitu ${ }^{1)}$ Bacillus subtilis strain $B R_{4} L G,{ }^{2)}$ Bacillus subtilis strain $\mathrm{BR}_{2} \mathrm{CL},{ }^{3)}$ Aneurinibacillus $s p$ strain $\mathrm{BT}_{4} \mathrm{LS}$, ${ }^{4)}$ Bacillus $s p$ strain $\mathrm{BT}_{3} \mathrm{CL}$, dan ${ }^{5)}$ Bacillus $s p$. strain $\mathrm{BT}_{8} \mathrm{XY}$ terbukti mampu berperanan sebagai starter decomposer, inokulan maupun biosuplemen dalam pengembangan usaha peternakan sapi bali (Mudita et al., 2019). Pemanfaatan teknologi Bio-BaliTani terbukti mampu menghasilkan silase pakan berbasis limbah pertanian berkualitas yang mampu meningkatkan produktivitas sapi bali (Mudita et al., 2019). Teknologi aplikatif yang praktis, mudah, dan tepat guna serta sangat potensial dikembangkan di kelompok tani tersebut.

Kegiatan pengabdian ini bertujuan untuk meningkatkan pengetahuan petani dan peternak Kelompok Tani Arsa Winangun melalui teknologi Bio-BaliTani dalam mengolah limbah ternak yang dihasilkan oleh kelompok tersebut. Dengan adanya teknologi ini, diharapkan para petani dan peternak dapat dengan mudah menghasilkan biourine yang berkualitas.

\section{METODE KEGIATAN}

Kegiatan ini merupakan salah satu rangkaian kegiatan PHP2D Fakultas Peternakan Universitas Udayana yang dilaksanakan di kelompok tani Arsa Winangun berlokasi di Banjar Dinas Taro Kaja, Tegallalang, Gianyar, Bali yang terdiri dari kegiatan sosialisasi dan pelatihan singkat yang bertempat di Yayasan Lembu Putih dilaksanakan selama 1 hari, serta dilanjutkan dengan kegiatan pendampingan (pembentukan demoplot) di khalayak sasaran dilaksanakan selama 2 bulan. Sosialisasi dan diseminasi teknologi yang dilakukan oleh seluruh team PHP2D dan beberapa narasumber, yaitu Prof. Dr. Ir. Ida Bagus Gaga Partama, MS yang membawakan materi aplikasi ilmu nutrisi ruminansia dalam pengembangan peternakan sapi bali di Desa Taro. Narasumber kedua yaitu Dr. I Made Mudita, S.Pt., 
MP (dosen pembimbing PHP2D) yang membawakan materi sosialisasi dan diseminasi IPTEKS BioBaliTani dalam optimalisasi usaha peternakan sapi bali.

Teknologi yang didesiminasikan di kelompok tani Arsa Winangun adalah teknologi pada pengolahan limbah kotoran ternak (padat mapun cair) menjadi pupuk organik. Produksi pupuk organik cair menggunakan teknologi Bio-BaliTani yang dilakukan dengan cara terlebih dahulu mencampur biourine dengan Bio-BaliTani dan molases dengan perbandingan setiap 100 liter biourine ditambahkan 1 liter Bio-BaliTani dan 1 liter molases, kemudian diaduk rata, lalu ditutup rapat selama $2-3$ minggu. Selanjutnya dilakukan fermentasi secara aerob dengan cara diaduk setiap harinya selama \pm 1 minggu. Setelah proses pengadukan baru dilanjutkan dengan pengemas.

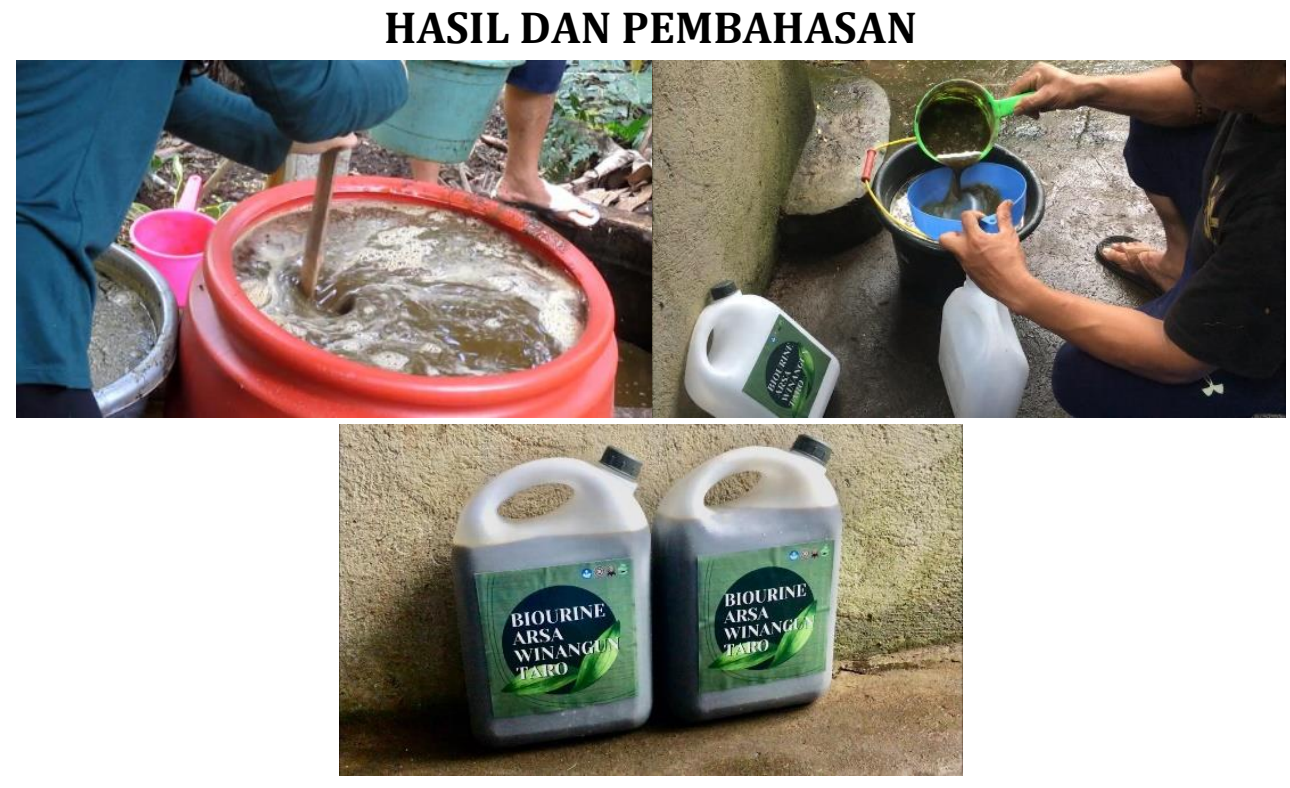

Gambar 1. Rangkaian Proses Produksi Pupuk Cair (Biourine)

Produk hasil kegiatan ini akan dievaluasi kualitasnya di di Laboratorium Tanah Fakultas Pertanian Universitas Udayana untuk analisis kandungan hara/nutrien dari pupuk organik. Dari pengujian yang telah dilakukan didapatkan hasil sebagai berikut.

Tabel 1. Kandungan Hara Pupuk Organik Hasil Pelaksanaan PHP2D

\begin{tabular}{ccccc}
\hline No & Kandungan Hara & Kandungan Hara ${ }^{1)}$ & Standar SNI & Keterangan \\
\hline 1 & Ph $(1: 2.5)$ & 7.13 & $6.80-7.79$ & Baik-agak alkalis \\
\hline 2 & C - organik (\%) & 0.39 & $9,8-32 \%$ & Kurang baik \\
\hline 3 & N total $(\%)$ & 0.02 & min. $0.4 \%$ & Kurang baik \\
\hline 4 & C/N ratio (\%) & 19.5 & min. 0.1\% & Sangat baik \\
\hline 5 & P Tersedia (ppm) & 130.17 & min. 0.1\% & Sangat baik \\
\hline 6 & K Tersedia (ppm) & 396 & min. 0.2\% & Sangat baik \\
\hline
\end{tabular}

Keterangan : ${ }^{1)}$ Hasil analisis Lab. Tanah Fakultas Pertanian Universitas Udayana, ${ }^{2)}$ Standar Nasional Indonesia 19-7030-2004

Berdasarkan hasil analisis hara atau nutrient dari produk yang dihasilkan bahwa daya hantar listrik serta kandungan fosfor dan kalium pada biourine sangat tinggi. Lalu kandungan karbon dan 
nitrogen sangat rendah. Kemudian $\mathrm{pH}$ pada biourine tersebut netral. Selain itu dalam keberhasian kegiatan ini 60 - 80\% masyarakat mendukung kegiatan mahasiswa dengan memberikan data dan memfasilitasi kegiatan yang diselenggarakan dan juga ikut secara langsung membuat pupuk dengan cara baru yang diberikan oleh dosen dan mahasiswa. Jumlah kelompok yang merasakan manfaat kegiatan mahasiswa (PHP2D) yaitu 22 orang anggota kelompok, mereka mendapat hal baru tentang pengolahan kotoran sapi menjadi produk yang akan lebih baik dari sebelumnya yang telah kelompok tersebut produksi. Peran masyarakat dalam pelaksanaan kegiatan pemberdayaan oleh mahasiswa (PHP2D) yaitu mendengarkan arahan atau pemahaman yang diberikan oleh bapak dosen dan mahasiswa tentang apa yang dapat membantu kelompok mengenai pakan sapi yang baik dan sesuai serta hanya bisa memfasilitasi tempat dan menyiapkan bahan, alat penunjang selama keperluan kegiatan ini.

\section{KESIMPULAN DAN SARAN}

Berdasarkan hasil analisis hara atau nutrient dari produk yang dihasilkan dapat disimpulkan bahwa produk biourine yang dihasilkan oleh Kelompok Tani Arsa Winangun mempunyai kualitas yang cukup baik, walaupun ada beberapa kandungan hara atau nutrient yang masih rendah (Tabel 1). Hal ini menunjukkan penerapan teknologi di khalayak sasaran berjalan cukup efektif dan berhasil dimana produk pupuk organik (biourine) mampu mengurangi pencemaran lingkungan dan mengangkat nilai jual limbah peternakan serta mampu menjaga lingkungan dari pencemaran. Hal-hal yang diterima masyarakat sasaran selama kegiatan pemberdayaan masyarakat yaitu mendapat ilmu baru melalui kegiatan ini, dan juga sangat terbantu akan pembuatan dan pengolahan pupuk organik dengan teknologi baru. Perubahan yang dirasakan kelompok tani tersebut sangat banyak setelah mengikuti kegiatan pemberdayaan masyarakat oleh mahasiswa dimana kelompok tani tersebut dapat mengolah kotoran sapi yang kurang bernilai lebih dan sekarang sudah bisa dijadikan pupuk yang sangat membantu kelompok tani tersebut dan bisa membantu perekonomian keluarga.

\section{UCAPAN TERIMAKASIH}

Ucapan terima kasih kami sampaikan kepada Kemendikbud atas bantuan hibah dalam kegiatan Program Holistik Pengembangan dan Pemberdayaan Desa oleh Kementrian Pendidikan dan Kebudayaan RI. Ucapan terima juga disampaikan kepada Rektor Unud, Dekan Fakultas Peternakan UNUD, Wakil Dekan III Fakultas Peternakan UNUD, Kepala Desa Taro Kaja, Dosen Pembimbing Dr. I Made Mudita, S.Pt., MP, dan Gubernur BEM KM FAPET UNUD, serta mitra atas bantuan, kerjasama dan partisipasinya hingga kegiatan terlaksana dengan baik

\section{DAFTAR PUSTAKA}

Mudita, I. M., Cakra, I. G. L. O., Mahardika, I. G., \& Sutama, I. N. S. (2019). Penapisan dan Pemanfaatan Bakteri Lignoselulolitik Cairan Rumen Sapi Bali dan Rayap Sebagai Inokulan dalam Optimalisasi Limbah Pertanian Sebagai Pakan Sapi Bali. [disertasi] Program Pascasarjana Peternakan, Universitas Udayana.

Mudita, I. M., Cakra, I. G. L. O., Wibawa, A. A. P. P., \& Siti, N. W. (2009). Penggunaan Cairan Rumen Sebagai Bahan Bioinokulan Plus Alternatif serta Pemanfaatannya dalam Optimalisasi Pengembangan Peternakan Berbasis Limbah yang Berwawasan Lingkungan. [Laporan Penelitian Hibah Unggulan] Universitas Udayana. 